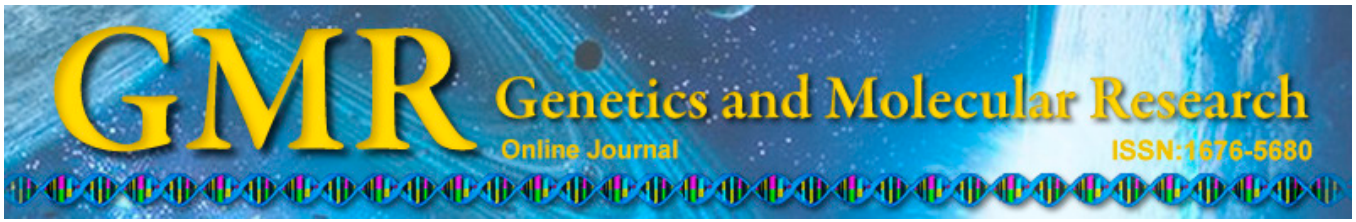

\title{
Kill curve analysis and response of first generation Capsicum annuum L. B12 cultivar to ethyl methane sulfonate
}

\author{
M.H. Arisha ${ }^{1,4}$, B.-K. Liang², S.N. Muhammad Shah ${ }^{1,5}$, \\ Z.-H. Gong ${ }^{1,3}$ and D.-W. $\mathrm{Li}^{1,3}$ \\ ${ }^{1}$ College of Horticulture, Northwest A\&F University, Yangling, Shaanxi, China \\ ${ }^{2}$ Seed Administration Station of Jintai District, Baoji, Shaanxi, China \\ ${ }^{3}$ State Key Laboratory for Stress Biology of Arid Region Crop, \\ Northwest A\&F University, Yangling, Shaanxi, China \\ ${ }^{4}$ Horticulture Department, Faculty of Agriculture, Zagazig University, \\ Zagazig, Egypt \\ ${ }^{5}$ Department of Horticulture, Faculty of Agriculture, \\ Gomal University, D.I. Khan, Pakistan \\ Corresponding author: Z.-H. Gong \\ E-mail: zhgong@nwsuaf.edu.cn
}

Genet. Mol. Res. 13 (4): 10049-10061 (2014)

Received July 29, 2014

Accepted November 11, 2014

Published November 28, 2014

DOI http://dx.doi.org/10.4238/2014.November.28.9

ABSTRACT. Pepper seeds (Capsicum annuum L.) var. B12 were mutagenized by four presoaking treatments in ten concentrations of ethyl methane sulfonate (EMS) to determine the sensitivity of the first generation (M1) to mutagens. The spectrum of mutations and induced variability for various quantitative traits, including germination, percent plant height, injury occurrence, survival ratio, first three fruits weight, and number of seeds per first fruit, were observed in the M1 generation. Our results indicated that all of the test parameters decreased with increasing EMS concentration, except for seedling injury. There were significant differences in germination ratio, $\mathrm{LD}_{50}$, plant height, percent injury, and survival ratio among the tested presoaking treatment. The 
$\mathrm{LD}_{50}$ was $1 \%$ EMS in seeds that were not presoaked (T1) and seeds presoaked for $12 \mathrm{~h}$ before treating with EMS (T3). In contrast, the $\mathrm{LD}_{50}$ was $0.5 \%$ EMS in seeds presoaked for $6 \mathrm{~h}$ (T2) and seeds presoaked in water for $6 \mathrm{~h}$ then incubated at $28^{\circ} \mathrm{C}$ for $12 \mathrm{~h}$ before EMS treatment (T4). Five dwarf plants were observed in mutagenized seeds without presoaking as compared to control seeds (at the maturity stage of the control plant).

Key words: Capsicum annuиm L.; Ethyl methane sulfonate; $\mathrm{LD}_{50}$; Seed presoaking conditions; Leaf abnormalities; Dwarf

\section{INTRODUCTION}

Pepper (Capsicum annuum L.) is one of the most important cultivated vegetable crops in tropical and subtropical regions. Therefore, enormous amounts of genetic diversity are required for crop improvement (Bosland, 1992). Ethyl methane sulfonate (EMS) is an alkylating agent with the formula $\mathrm{CH}_{3} \mathrm{SO}_{3} \mathrm{C}_{2} \mathrm{H}_{5}$. It is a common, powerful, and effective chemical mutagen (Chopra, 2005) used to create mutations in pepper plants (Sharma and Kumar, 2003). It produces random mutations in genetic material by nucleotide substitution with base pair transition (G:C to A:T), thereby producing only point mutations without killing the plants (Greene et al., 2003). In seed-propagated plants, such as peppers, chemical mutagenesis protocols use seeds during the germination process, thus causing the mutagen to be absorbed by the germinating embryo and reach the meristematic region, where the germ cell is present (Serrat et al., 2014). The EMS concentration that yields $50 \%$ seed lethality $\left(\mathrm{LD}_{50}\right)$ is used as an indicator of high mutation frequency (Devi and Selvakumar, 2013). Determination of the concentration that gives the highest desired mutation frequency is important but difficult. While using higher concentrations increases mutation frequency, it also increases the probability of undesirable mutations that cause sterility or lethality. In contrast, using a relatively low concentration results in a lower mutation frequency. Many factors play a vital role in determining the effectiveness of EMS concentration, such as presoaking time and method, duration of EMS exposure, temperature during treatment, and $\mathrm{pH}$ value of phosphate buffer. This study focuses on the method and duration of seed presoaking in water before EMS treatment, which controls the effectiveness of the EMS concentration. The objective of this study was to observe the effect of EMS on plant behavior including germination, seedling growth, survival ratio, fruit weight, and phenotypic changes during the first generation. These data will contribute to the selection of mutant plants for the second generation.

\section{MATERIAL AND METHODS}

\section{Plant material}

The pepper seeds (Capsicum annuum L.) cultivar B12, used in this experiment were provided by the Capsicum research group, College of Horticulture, Northwest A\&F University. 


\section{Ethyl methane sulfonate (EMS) treatments}

Pepper seeds were subjected to eleven EMS concentration, including the control $(0,0.25,0.50,0.75,1.00,1.25,1.50,1.75,2.00,2.25,2.50 \% \mathrm{v} / \mathrm{v})$ and three different presoaking durations in distilled water [0 (T1), 6 (T2) and $12 \mathrm{~h}$ (T3)]. In addition, seeds were presoaked in water for $6 \mathrm{~h}$ then incubated for $12 \mathrm{~h}$ at $28^{\circ} \mathrm{C}$ before treating with the abovementioned EMS concentrations (T4). In all treatments, the seeds treated were washed by running water for $3 \mathrm{~h}$. Treated and untreated (control) seeds were germinated on petri dishes and then sown in pots. Twenty-five seeds were used for each treatment, and each treatment was replicated twice.

\section{Parameters studied}

\section{Germination test}

Seeds were germinated on petri dishes $(9 \mathrm{~cm})$ on 4 layers of Whatman No. 1 filter paper, moistened with distilled water. Petri dishes were placed at $25^{\circ} \pm 2^{\circ} \mathrm{C}$ under a $16: 8 \mathrm{~h}$ (day: night) photoperiod in an incubator (Farooq et al., 2008). The experiment was performed following a completely randomized design with two replicates. Seeds with visible radicals (radical length equal to half of seed diameter, about $1 \mathrm{~mm}$ ) were considered germinated and data were recorded according to the methods of the Association of Official Seed Analysis (1990). Germination percent (GP) was calculated 7 days after germination, according to Dezfuli et al., (2008) using following formula:

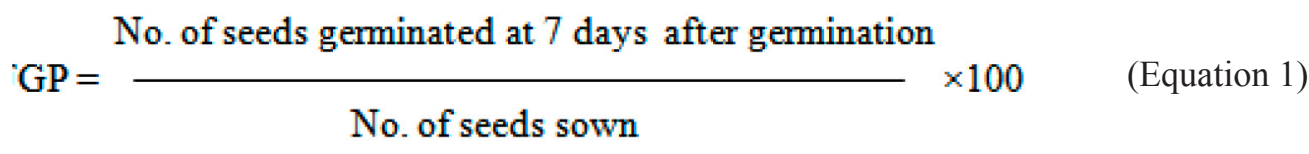

\section{Plant growth performance}

After calculating the germination parameters, seeds were transferred into a suitable growth media (compost) in pots and the following data regarding seedling growth performance were recorded:

\section{Plant height}

Plant height $(\mathrm{cm})$ was estimated when the fruit of the surviving plants were harvested for each treatment and the control (Dezfuli et al., 2008).

\section{Injury percent}

Seedling injury was measured by the percent reduction in plant height as compared to control (Bashir, 2012) as follows: 


\section{Percent injury $=\frac{\text { Control-Treated }}{\text { Control }} \times 100 \quad$ Equation 2 \\ Control}

\section{Survival ratio}

The surviving plants in different treatments were counted on day 42 , and the survival percentage was calculated according to Bashir (2012) by the following formula:

$$
\text { Survival } \%=\frac{\text { No. of seedlings survived }}{\text { No. of seeds germinated }} \times 100 \quad \text { Equation } 3
$$

\section{Fruit characteristics}

\section{Fruit weight}

Fruit weight was recorded by measuring the weight of the first three fruits.

\section{Number of seeds per first fruit}

Number of seeds per first fruit was counted after harvesting.

\section{Dwarfism} to maturity.

Plant height was assessed during the developmental time course from germination

\section{Statistical Analysis}

Statistical analyses were conducted for all collected data using the Statistix 9 (2008) according to the methodology given by Snedecor and Cochran (1980) and the least significant difference test $(\mathrm{P}<0.05)$ was used to investigate the significant differences among the treatments for all tested parameters. Dunnett's multiple comparisons test was performed using the GraphPad Prism version 6.00 for Windows, (GraphPad, 2014).

\section{RESULTS AND DISCUSSION}

\section{Germination percentage (GP) and $L D_{50}$}

Using germinating seeds for mutagenesis requires that the mutagen be absorbed by the germinating embryo and reach the meristemic region where the germ cells are contained. Thus, mutagenesis can affect the percent germination (Serrat et al., 2014). As shown in Figure 1 , a significant reduction in seed germination was observed with increasing EMS concentrations $(\mathrm{P} \leq 0.05)$. 


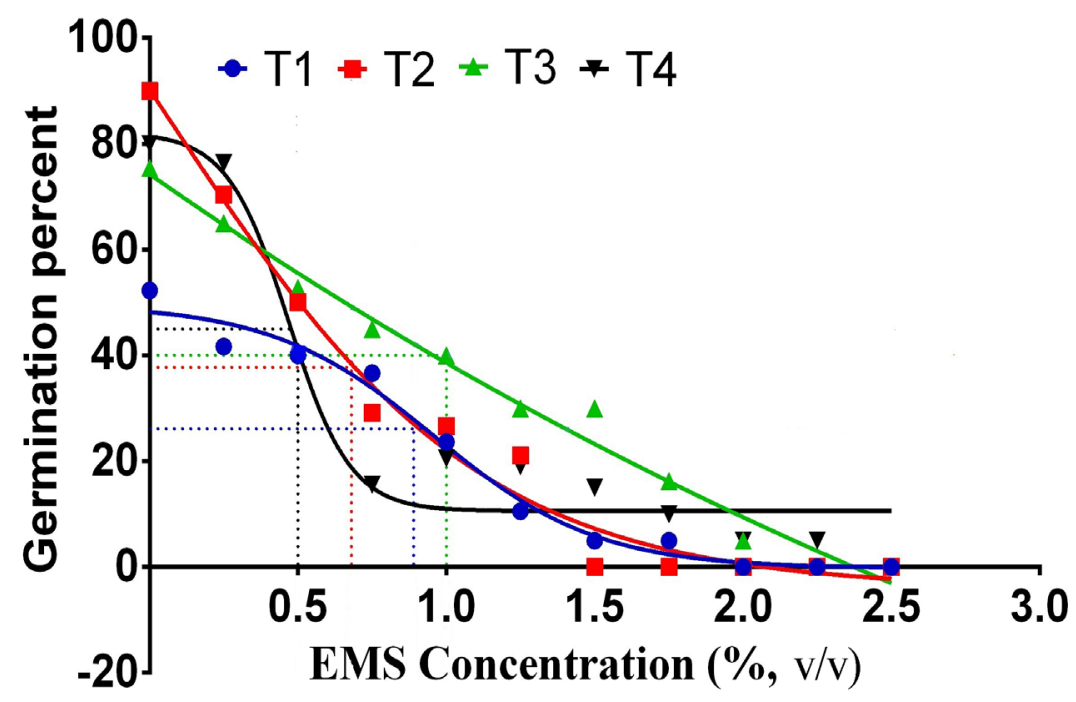

Figure 1. Effect of different ethyl methane sulfonate (EMS) concentrations and seed presoaking conditions on germination percent and determination of $\mathrm{LD}_{50}$ after 7 days. EMS = Ethyl methane sulfonate; $\mathrm{T} 1=$ seeds treated directly with EMS without presoaking in water; T2 = seeds presoaked in water for 6 hours before EMS treatment; $\mathrm{T} 3$ = seeds presoaked in water for $12 \mathrm{~h}$ before EMS treatment; and T4 = seeds presoaked in water for 6 hours then incubated at $28^{\circ} \mathrm{C}$ for 12 hours before EMS treatment.

This reduction in germination (Talebi et al., 2012) may be due to the delay or inhibition of physiological and biological processes considered necessary for seed germination, including enzyme activity (Devi and Mullainathan, 2011), hormonal imbalance (Borovsky et al., 2013), and inhibition of mitotic processes (Kumar and Gupta, 2009). Further, germination may be inhibited due to the toxic nature of the mutagen (Kumar et al., 2013), damage to cell constituents at the molecular level, or altered enzyme activity (Khan and Goyal, 2009). As expected, the highest germination ratio was observed with the control treatment, irrespective of all presoaking treatments. T1 seed germination was restricted with by EMS concentrations more than $1.75 \%$, and the $\mathrm{LD}_{50}$ was $1 \%$ EMS. Further, doses of 2, 2.25, and $2.5 \%$ EMS were fully lethal. Using the $\mathrm{T} 2$ treatment, the $\mathrm{LD}_{50}$ was $0.5 \%$ EMS, while 1.5 to $2.5 \%$ EMS was fully lethal. Furthermore, the $\mathrm{LD}_{50}$ in the T3 treated seeds was 1\% EMS (with presoaking for $12 \mathrm{~h}$ ), whereas no germination was observed at 2.25 and 2.5\% EMS. Using the T4 treatment, the germination ratio was decreased with increasing EMS concentration up to $2.25 \%$, and the $\mathrm{LD}_{50}$ was observed at $0.5 \%$ EMS, whereas $2.5 \%$ EMS killed all seeds. According to Devi and Selvakumar (2013) the decreasing trend in pepper germination with increasing EMS concentration may be attributed to seed germination without completely developed embryos. Furthermore, EMS can cause DNA in the embryo, thereby increasing the time to germination (Greer and Rinehart, 2009). The presoaking method and duration before EMS treatment can affect the concentration that reduces the germination ratio to $50 \%$ and gives the highest mutation rate (Sathawane, 2012). The present results indicated that T2 and T4 treatments were more effective for obtaining the $\mathrm{LD}_{50}$ with lower concentrations $(0.5 \% \mathrm{EMS})$, as compared to $\mathrm{T} 1$ and $\mathrm{T} 3$ (1\% EMS). Similarly, presoaking canola seeds in water increased mutagen penetration into seeds and had a greater effect on metabolic activity (Fowler and Stefansson, 1972). Further, Devi and Selvakumar (2013) found that the $\mathrm{LD}_{50}$ was observed when pepper seeds were pre- 
soaked for $12 \mathrm{~h}$ prior to EMS treatment. In addition, Sathawane (2012) compared presoaked and non-presoaked seeds before EMS treatment in Brassica juncea, and found that, in the M1 generation, treating dry seeds with lower EMS concentrations for $18 \mathrm{~h}$ produced mutants with yellow seed coats (frequency $=0.35 \%$ ) at a higher rate than increased doses of EMS.

\section{Seedling growth performance}

\section{Plant height}

Plant height can be used as an important indicator for determining the biological effects of EMS (Devi and Mullainathan, 2011). As shown in Figure 2, the plant height was significantly decreased with increasing EMS concentrations. This reduction in plant height has been attributed to auxin destruction, changes in ascorbic acid content, and physiological and biochemical disturbances (Dhamayanthi and Reddy, 2000).

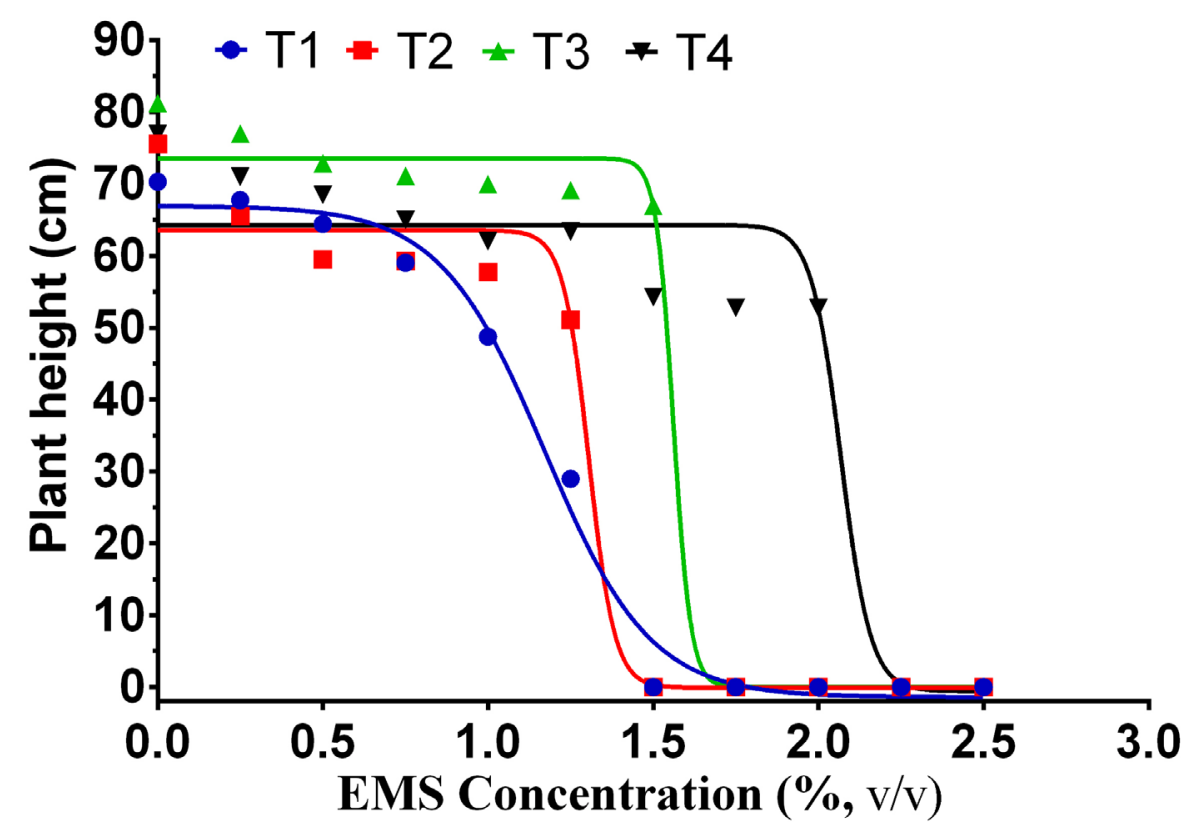

Figure 2. Effect of different ethyl methane sulfonate (EMS) concentrations and seed presoaking conditions on plant height at the maturity stage of the control plants. EMS = Ethyl methane sulfonate; $11=$ seeds treated directly with EMS without presoaking in water; T2 = seeds presoaked in water for 6 hbefore EMS treatment; T3 = seeds presoaked in water for $12 \mathrm{~h}$ before EMS treatment; and T4 = seeds presoaked in water for $6 \mathrm{~h}$ then incubated at $28^{\circ} \mathrm{C}$ for $12 \mathrm{~h}$ before EMS treatment.

In addition, plant height was reduced with increasing EMS concentrations in black gram (Deepalakshmi and Anandakumar, 2004), canola plants (Emrani et al., 2011), and wheat (Bahar and Akkaya, 2009). Moreover, treating pepper seeds with $0.5 \%$ EMS for $7 \mathrm{~h}$ significantly decreased the plant height (Kumar and Gupta 2009). Here, treating pepper seeds with EMS doses higher than $1.25 \%$ significantly reduced the plant height and caused more variation which may be considered an indicator of increased mutation frequency. In accordance 
with the present results, the maximum variation was observed with high EMS concentrations compared to controls in tomato plants (Saba and Mirza, 2002) and pepper (Patil et al., 1997). Among all the presoaking treatments, plants undergoing the control treatment ( $0 \%$ EMS) were the tallest, and height was significantly decreased by increasing EMS concentrations. In this respect, T4 plants were taller than T3, although the difference was not significant. In contrast, $\mathrm{T} 2$ and $\mathrm{T} 1$ treated plants were smaller, and recorded the lowest values, although there was no significant difference between them. The lowest values were observed at 1.25, 1.25, 1.5, and $2 \%$ EMS in T1, T2, T3, and T4 plants, respectively (Figure 2). This may be because exposing dry seeds and seeds presoaked for $6 \mathrm{~h}$ to EMS solution causes the non-presoaked seeds to absorb more EMS solution than presoaked seeds, thereby directly affecting the embryo.

\section{Injury percent (IP)}

The degree of injury caused by EMS is usually correlated with the frequency of mutations. Therefore, a quantitative determination of injury is commonly used to indicate the effectiveness of the mutagen treatment (Constantin, 1975). Among the four presoaking treatments, IP was significantly increased with increasing EMS concentrations (Figure 3).

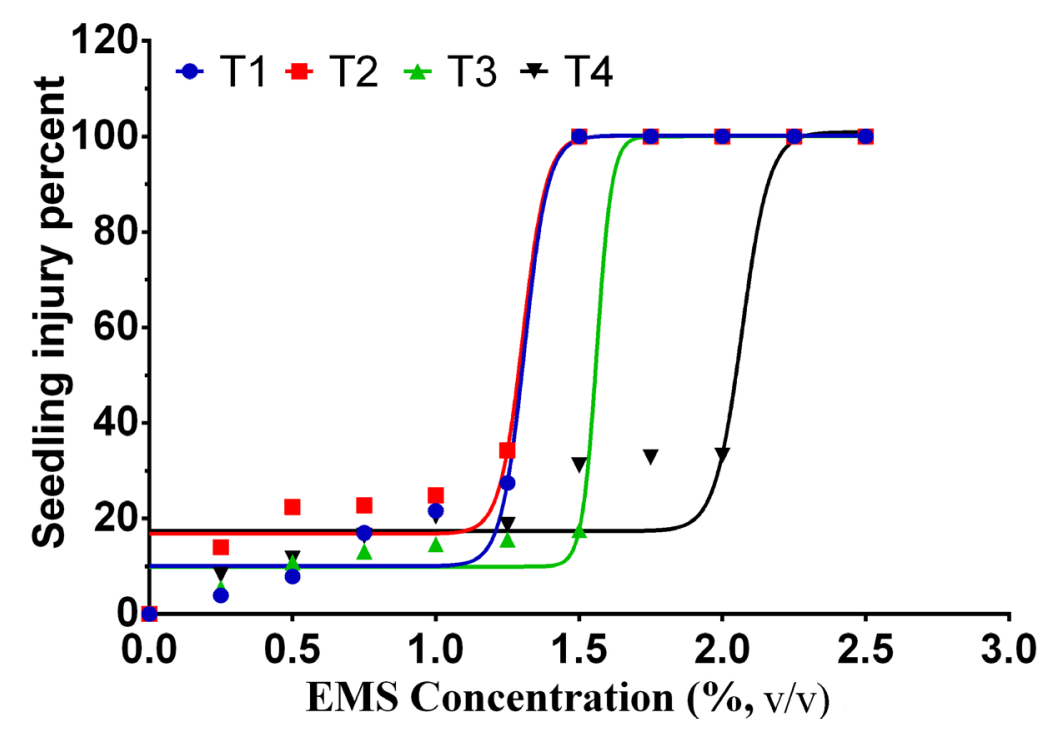

Figure 3. Effect of different ethyl methane sulfonate (EMS) concentrations and seed presoaking conditions on injury percent. EMS = Ethyl methane sulfonate; $\mathrm{T} 1$ = seeds treated directly with EMS without presoaking in water; $\mathrm{T} 2=$ seeds presoaked in water for $6 \mathrm{~h}$ before EMS treatment; T3 = seeds presoaked in water for $12 \mathrm{~h}$ before EMS treatment; and T4 $=$ seeds presoaked in water for $6 \mathrm{~h}$ then incubated at $28^{\circ} \mathrm{C}$ for $12 \mathrm{~h}$ before EMS treatment.

EMS at concentrations greater than $1.25 \%$ using $\mathrm{T} 1$ and $\mathrm{T} 2$ caused the maximum seedling injury (100\%), whereas $100 \%$ IP was induced using more than $1.5 \%$ EMS in T3. Furthermore, seedlings obtained from T4 were less affected by increasing EMS concentrations up to $2 \%$. However, at concentrations greater than $2 \%, 100 \%$ of the seedlings were injured. That may be due to the use of different presoaking treatments before EMS treatment, which may affect the quantity of EMS absorbed by the germinating embryo. Injury is also dependent on 
the quantity of EMS that reaches the meristematic region where the germ cells are contained (Serrat et al., 2014). In cotton plants, Aslam et al. (2013) observed that the percent of injury increased with increasing EMS concentration.

\section{Survival ratio (SR)}

The pooled mean values of the survival percentage indicated maximum survival occurred in control cells and decreased gradually with increasing EMS concentrations (Figure 4).

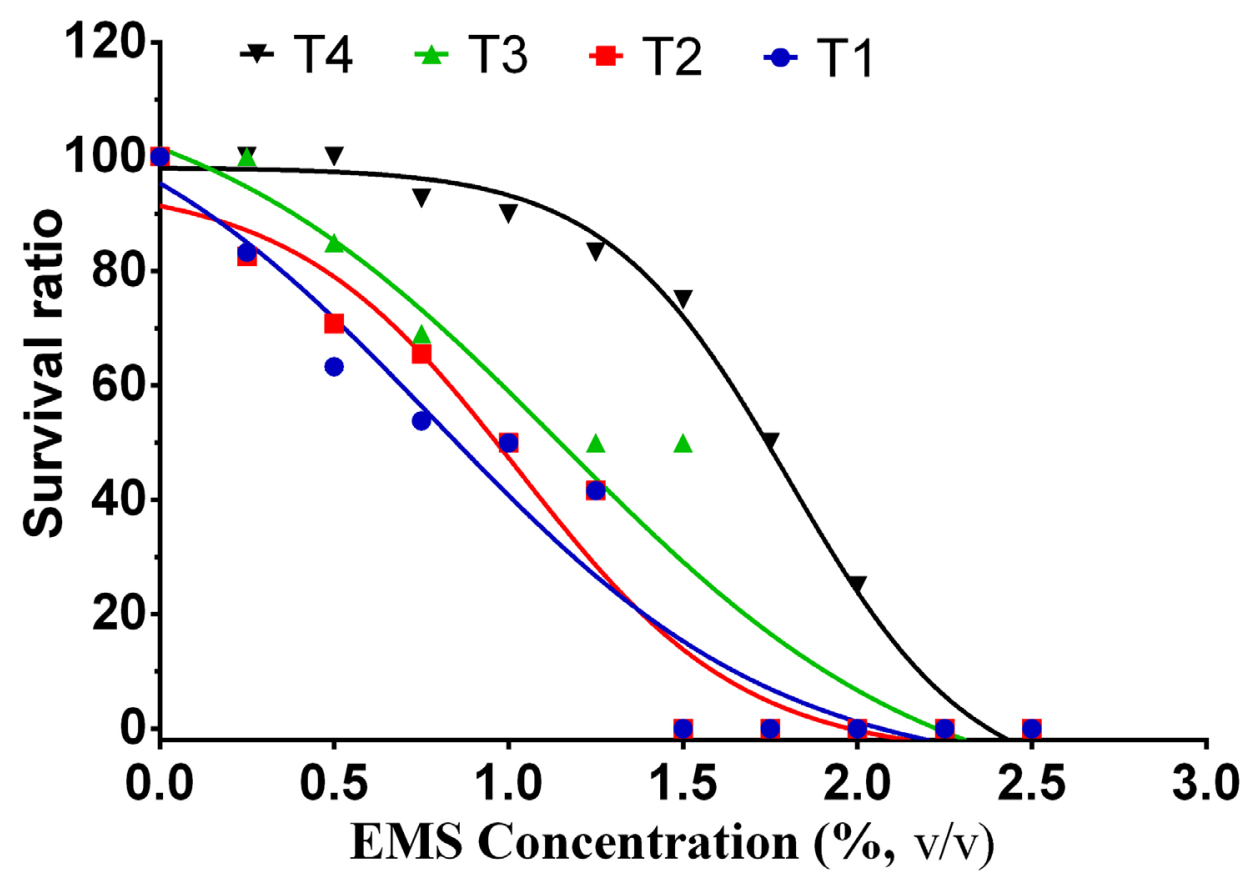

Figure 4. Effect of different ethyl methane sulfonate (EMS) concentrations and seed presoaking conditions on survival ratio. EMS = Ethyl methane sulfonate; $\mathrm{T} 1$ = seeds treated directly with EMS without presoaking in water; $\mathrm{T} 2=$ seeds presoaked in water for $6 \mathrm{~h}$ before EMS treatment; T3 = seeds presoaked in water for $12 \mathrm{~h}$ before EMS treatment; and $\mathrm{T} 4=$ seeds presoaked in water for $6 \mathrm{~h}$ then incubated at $28^{\circ} \mathrm{C}$ for $12 \mathrm{~h}$ before EMS treatment.

Increasing EMS concentrations can harm the embryo or affect the physiological and biological processes (Devi and Mullainathan, 2012) that regulate seedling growth, causing the embryos to become weak or die, depending on the intensity of the embryonic damage. The effect of presoaking and EMS concentrations on SR was clearer with high EMS concentrations (more than $1.25 \%$ ). About $75 \%$ of seedlings survived in the T1 and T2 groups at a relatively low EMS concentrations (between 0.25 and $0.50 \%$ EMS), whereas higher concentrations were observed with T3 (between 0.50 and $0.75 \%$ EMS) and T4 (1.5\% EMS). Moreover, T4 combined with $0.5 \%$ EMS resulted in a $100 \%$ SR, similar to the control treatment ( $0 \%$ EMS). Devi and Selvakumar (2013), found that treating pepper seeds (C. annuum) with EMS at 30 $\mathrm{mM}$ decreased the survival rate and resulted in a $50 \%$ germination ratio $\left(\mathrm{LD}_{50}\right)$. In our study, seedlings obtained from T2 and T1 were strongly affected by higher EMS concentrations, re- 
sulting in a lower survival ratio compared to T3 treatment. In contrast, T4 recorded the highest survival ratio. It is possible that, in the T4 embryos and seeds, biological activity was activated by presoaking seeds for $6 \mathrm{~h}$ and incubating them at a suitable temperature. The presoaking method and duration can regulate the deleterious effect of EMS on Brassica napus seeds (Emrani et al., 2011). Thus, presoaking seeds in water increases the penetration of mutagens into the seeds and led to a greater effect on metabolic activities, thereby increasing the effectiveness of EMS at relatively low concentrations (Fowler and Stefansson, 1972). In addition, the interdependence of treatment variables that influence the degree of seed lethality induced by a mutagen is clearly illustrated by the interactions between EMS concentration, treatment period, and seed presoaking (Emrani et al., 2011).

\section{Fruit characters}

\section{Fruits weight}

The fruit weight, measured as the sum weight of the first 3 fruits, is shown in Table 1.

Table 1. Effect of seed presoaking conditions, ethyl methane sulfonate (EMS) concentrations, and their interaction on the weight of the first three fruits of M1 plants.

\begin{tabular}{|c|c|c|c|c|c|}
\hline Treatments & $\mathrm{T} 1$ & $\mathrm{~T} 2$ & $\mathrm{~T} 3$ & $\mathrm{~T} 4$ & Mean \\
\hline $0.00 \%, \mathrm{~V} / \mathrm{V}$ EMS & $127.50^{\mathrm{a}}$ & $126.65^{\mathrm{A}}$ & $128.44^{a}$ & $130.31^{\mathrm{a}}$ & $128.23^{\mathrm{A}}$ \\
\hline $0.25 \%, \mathrm{~V} / \mathrm{V}$ EMS & $103.04^{\mathrm{bc}}$ & $104.79^{\mathrm{Bc}}$ & $124.55^{\mathrm{a}}$ & $119.45 \mathrm{a}^{\mathrm{b}}$ & $112.95^{\mathrm{B}}$ \\
\hline $0.50 \%, \mathrm{~V} / \mathrm{V}$ EMS & $100.53^{\mathrm{c}}$ & $75.30^{\mathrm{e}-\mathrm{g}}$ & $96.24^{\mathrm{cd}}$ & $103.18 b^{c}$ & $93.81^{\mathrm{C}}$ \\
\hline $0.75 \%, \mathrm{~V} / \mathrm{V}$ EMS & $78.64^{\mathrm{e}-\mathrm{f}}$ & $60.41^{\mathrm{g}-\mathrm{i}}$ & $89.76^{\mathrm{c}-\mathrm{e}}$ & $91.58^{\mathrm{c}-\mathrm{e}}$ & $80.09^{\mathrm{D}}$ \\
\hline $1.00 \%, \mathrm{~V} / \mathrm{V}$ EMS & $69.68^{\mathrm{fth}}$ & $57.68^{\mathrm{Hi}}$ & $80.28^{\mathrm{d}-\mathrm{f}}$ & $81.22^{\mathrm{d}-\mathrm{f}}$ & $72.21^{\mathrm{D}}$ \\
\hline $1.25 \%, \mathrm{~V} / \mathrm{V}$ EMS & $44.40^{\mathrm{i}-\mathrm{k}}$ & $43.76^{\mathrm{i}-\mathrm{k}}$ & $47.17^{\mathrm{ik}}$ & $74.86^{\mathrm{e}-\mathrm{h}}$ & $52.55^{\mathrm{E}}$ \\
\hline $1.50 \%, \mathrm{~V} / \mathrm{V}$ EMS & $00.00^{1}$ & $00.00^{\mathrm{L}}$ & $39.68^{\mathrm{jk}}$ & $50.95^{\mathrm{ij}}$ & $22.66^{\mathrm{F}}$ \\
\hline $1.75 \%, \mathrm{~V} / \mathrm{V}$ EMS & $00.00^{1}$ & $00.00^{\mathrm{L}}$ & $00.00^{1}$ & $46.14^{i-k}$ & $11.53^{\mathrm{G}}$ \\
\hline $2.00 \%, \mathrm{~V} / \mathrm{V}$ EMS & $00.00^{1}$ & $00.00^{\mathrm{L}}$ & $00.00^{1}$ & $30.30^{k}$ & $07.57^{\mathrm{GH}}$ \\
\hline $2.25 \%, \mathrm{~V} / \mathrm{V}$ EMS & $00.00^{1}$ & $00.00^{\mathrm{L}}$ & $00.00^{1}$ & $00.00^{1}$ & $00.00^{\mathrm{H}}$ \\
\hline $2.50 \%, \mathrm{~V} / \mathrm{V}$ EMS & $00.00^{1}$ & $00.00^{\mathrm{L}}$ & $00.00^{1}$ & $00.00^{1}$ & $00.00^{\mathrm{H}}$ \\
\hline Mean & $47.62^{\mathrm{C}}$ & $42.60^{\mathrm{C}}$ & $55.10^{\mathrm{B}}$ & $66.18^{\mathrm{A}}$ & \\
\hline
\end{tabular}

$\mathrm{T} 1=$ seeds treated directly with EMS without presoaking in water; T2 $=$ seeds presoaked in water for $6 \mathrm{~h}$ before EMS treatment; T3 = seeds presoaked in water for 12 hours before EMS treatment; and T4 = seeds presoaked in water for $6 \mathrm{~h}$ then incubated at $28^{\circ} \mathrm{C}$ for 12 hours before EMS treatment. Different small superscript letters indicate significant differences, determined by Duncan's multiple range at $\mathrm{P}=0.05$.

The first three fruit weight decreased with increasing EMS concentrations compared to the control (Table 1). The reduction of these parameters was prominent in the T1, T2, and T3 treatment, as compared to T4. The effects of EMS were reported in several other crops (Reddy et al., 1992) and in peppers (Gandhi et al, 2014). The mutagenic effect was found to decrease the quantitative characteristics of soybeans (Pavadai and Dhanavel, 2004) and cluster beans (Velu et al., 2007). The first generation (M1) developed from treated seeds suffered from growth inhibition, may be partly sterile, and may lose many plants before flowering and producing seeds (Ojiewo et al., 2006).

\section{Number of seeds in the first fruit}

EMS affects the number of seeds per fruit in the first generation, as shown in Table 2. 
Table 2. Effect of seed presoaking conditions, ethyl methane sulfonate (EMS) concentrations, and their interaction on the number of seeds per first fruit of M1 plants.

\begin{tabular}{|c|c|c|c|c|c|}
\hline Treatments & $\mathrm{T} 1$ & $\mathrm{~T} 2$ & $\mathrm{~T} 3$ & $\mathrm{~T} 4$ & Mean \\
\hline $0.00 \%, \mathrm{~V} / \mathrm{V}$ EMS & $74.37^{\mathrm{ab}}$ & $77.26^{\mathrm{ab}}$ & $80.56^{\mathrm{a}}$ & $79.00^{\mathrm{Ab}}$ & $77.80^{\mathrm{A}}$ \\
\hline $0.25 \%, \mathrm{~V} / \mathrm{V}$ EMS & $69.73^{\mathrm{a}-\mathrm{c}}$ & $69.35^{\mathrm{a}-\mathrm{c}}$ & $67.82^{\mathrm{bc}}$ & $68.50^{\mathrm{a}-\mathrm{c}}$ & $68.85^{\mathrm{B}}$ \\
\hline $0.50 \%, \mathrm{~V} / \mathrm{V}$ EMS & $61.95^{\mathrm{c}}$ & $60.66^{\mathrm{C}}$ & $61.88^{c}$ & $59.00^{\mathrm{Cd}}$ & $60.87^{\mathrm{C}}$ \\
\hline $0.75 \%, \mathrm{~V} / \mathrm{V}$ EMS & $48.22^{\mathrm{de}}$ & $47.86^{\mathrm{de}}$ & $44.02^{\mathrm{ef}}$ & $46.00^{\mathrm{Ef}}$ & $46.53^{\mathrm{D}}$ \\
\hline $1.00 \%, \mathrm{~V} / \mathrm{V}$ EMS & $44.99^{\mathrm{ef}}$ & $39.50^{\mathrm{e}-\mathrm{g}}$ & $43.55^{\text {ef }}$ & $45.50^{\mathrm{Ef}}$ & $43.37^{\mathrm{DE}}$ \\
\hline $1.25 \%, \mathrm{~V} / \mathrm{V}$ EMS & $38.20^{\mathrm{e}-\mathrm{g}}$ & $35.60^{\mathrm{f}-\mathrm{h}}$ & $41.50^{\mathrm{e}-\mathrm{g}}$ & $38.57^{\mathrm{e}-\mathrm{g}}$ & $38.32^{\mathrm{E}}$ \\
\hline $1.50 \%, \mathrm{~V} / \mathrm{V}$ EMS & $00.00^{\mathrm{i}}$ & $00.00^{\mathrm{i}}$ & $34.50^{\mathrm{f}-\mathrm{h}}$ & $35.50^{\mathrm{f}-\mathrm{h}}$ & $17.50^{\mathrm{F}}$ \\
\hline $1.75 \%, \mathrm{~V} / \mathrm{V}$ EMS & $00.00^{\mathrm{i}}$ & $00.00^{\mathrm{i}}$ & $00.00^{\mathrm{i}}$ & $29.94^{g-h}$ & $07.49^{\mathrm{G}}$ \\
\hline $2.00 \%, \mathrm{~V} / \mathrm{V}$ EMS & $00.00^{\mathrm{i}}$ & $00.00^{\mathrm{i}}$ & $00.00^{\mathrm{i}}$ & $24.50^{\mathrm{H}}$ & $06.13^{\mathrm{GH}}$ \\
\hline $2.25 \%, \mathrm{~V} / \mathrm{V}$ EMS & $00.00^{\mathrm{i}}$ & $00.00^{\mathrm{i}}$ & $00.00^{\mathrm{i}}$ & $00.00^{1}$ & $00.00^{\mathrm{H}}$ \\
\hline $2.50 \%, \mathrm{~V} / \mathrm{V}$ EMS & $00.00^{\mathrm{i}}$ & $00.00^{\mathrm{i}}$ & $00.00^{\mathrm{i}}$ & $00.00^{1}$ & $00.00^{\mathrm{H}}$ \\
\hline Mean & $30.68^{\mathrm{BC}}$ & $29.97^{\mathrm{C}}$ & $33.98^{\mathrm{B}}$ & $38.77^{\mathrm{A}}$ & \\
\hline
\end{tabular}

$\mathrm{T} 1=$ seeds treated directly with EMS without presoaking in water; $\mathrm{T} 2=$ seeds presoaked in water for 6 hours before EMS treatment; T3 = seeds presoaked in water for 12 hours before EMS treatment, and T4 = seeds presoaked in water for $6 \mathrm{~h}$ then incubated at $28^{\circ} \mathrm{C}$ for 12 hours before EMS treatment. Different small superscript letters indicate significant differences, determined by Duncan's multiple range at $\mathrm{P}=0.05$.

Increasing EMS concentrations significantly decreased the average number of seeds per first fruit. The number of seeds per first fruit in the treated seeds was significantly higher in untreated seeds, as compared to treated seeds. In accordance with these findings Gandhi et al (2014) reported that treating seeds with EMS yielded a different seed ratio in the first generation (M1) fruits.

\section{Dwarfism}

In this study, dwarf plants were characterized on a morphological basis, compared to the control plants at the age of fruit maturity. There were 5 dwarf plants having heights of 4.02, 6.5, 3,4 , and $2 \mathrm{~cm}$, whereas the average control plant height was $65.81 \mathrm{~cm}$ (Table 3 and Figure 5).

Table 3. Mean performance of dwarf plants compared to the control at maturity stage.

\begin{tabular}{|c|c|c|c|c|c|c|c|c|}
\hline Plant & Treatment & $\mathrm{D} / \mathrm{N}$ & No. of leaves/plant & Height (cm) & Internode length $(\mathrm{cm})$ & $\mathrm{N}_{\mathrm{f}}$ & No. of flowers/plant & No. of fruits/plant \\
\hline$\overline{\mathrm{CK}}$ & Control & - & 43 & 75.81 & 5.50 & 5 & 17 & 5 \\
\hline 1 & $\mathrm{~T} 1 \mathrm{x} 0.50$ & $1 / 6$ & 7 & 04.02 & 0.50 & 3 & 2 & 0 \\
\hline 2 & $\mathrm{~T} 1 \times 0.75$ & $1 / 8$ & 8 & 06.50 & 0.93 & 6 & 1 & 0 \\
\hline 3 & $\mathrm{~T} 1 \times 1.00$ & $1 / 10$ & 9 & 03.00 & 0.50 & 5 & 5 & 0 \\
\hline 4 & $\mathrm{~T} 1 \times 1.25$ & $1 / 8$ & 6 & 04.00 & 0.80 & 4 & 3 & 0 \\
\hline 5 & $\mathrm{~T} 1 \times 1.25$ & $1 / 8$ & 6 & 02.00 & 0.67 & 3 & 1 & 1 \\
\hline
\end{tabular}

EMS = ethyl methane sulfonate; $\mathrm{CK}=$ control treatment; $\mathrm{D} / \mathrm{N}=$ number of dwarf plants/total number of plants; $\mathrm{N}_{\mathrm{f}}$ $=$ No. of node which beard the first flower; $\mathrm{T} 1=$ seeds treated directly with EMS without presoaking in water. $1=$ $\mathrm{T} 1 \times 0.50$ (v/v, \%) EMS; 2 = T1 x 0.75 (v/v, \%) EMS; 3 = T1 x 1.00 (v/v, \%) EMS; $4=\mathrm{T} 1$ x 1.25 (v/v, \%) EMS; 5 $=\mathrm{T} 1 \times 1.25(\mathrm{v} / \mathrm{v}, \%)$ EMS.

All the dwarf plants were observed in the T1 treatment group (seeds treated directly with EMS without presoaking in water). These findings suggest that the dry seeds were able to absorb more mutagen than other presoaking treatments. Jabeen and Mirza, (2002) found that using $0.5 \%$ EMS with $6 \mathrm{~h}$ exposure is highly toxic and has drastic effects on embryo, which greatly affects the plant height. It is also clear from Table 3 that these dwarf plants are significantly different than the control plants in internode length, number of node beard the first flowers, number of flowers per plant and number of fruits per plant as shown in Table 3. In agree 
with this study Jabeen and Mirza, (2004) treated pepper seeds (Longhi cultivar) with EMS and observed morphological mutations, including dwarfism, sterility, early maturing, and late maturing.

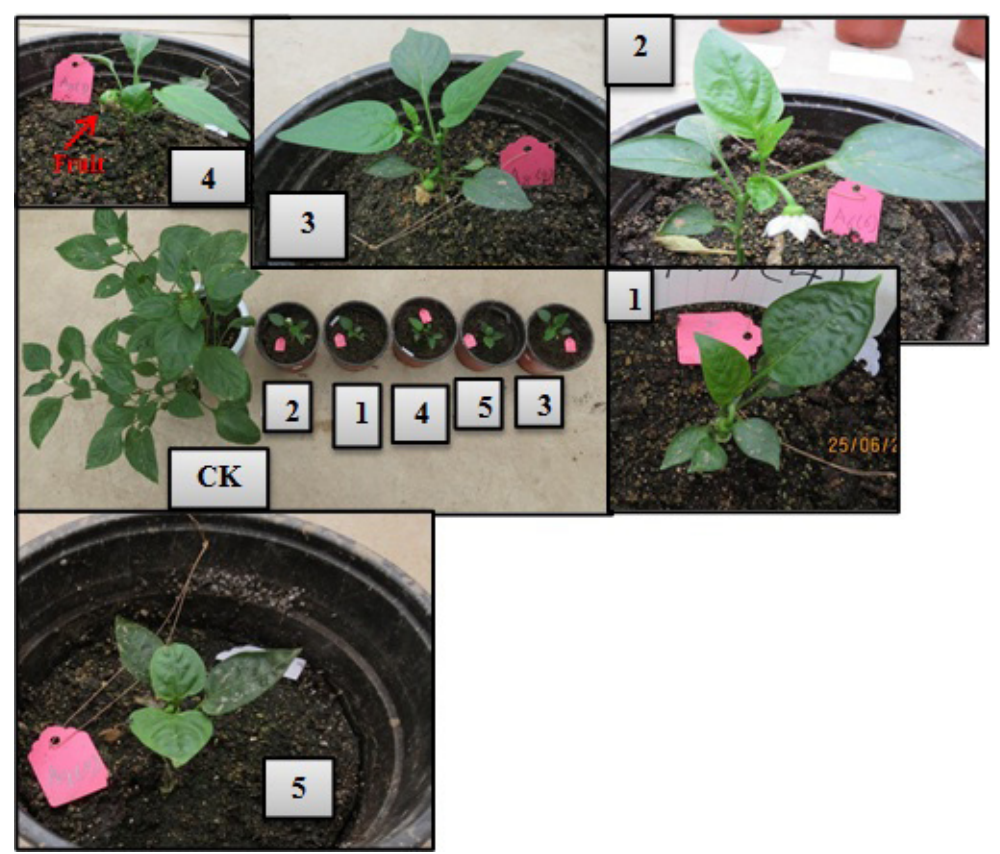

Figure 5. Dwarf plants observed in $\mathrm{T} 1$ treatment at the time of maturity in control plants. EMS = ethyl methane sulfonate; $\mathrm{CK}=$ control treatment; $\mathrm{T} 1=$ seeds treated directly with EMS without presoaking in water; $1=\mathrm{T} 1 \mathrm{X}$ $0.50(\mathrm{v} / \mathrm{v}, \%) \mathrm{EMS} ; 2$ = T1 $10.75(\mathrm{v} / \mathrm{v}, \%) \mathrm{EMS} ; 3$ = T1 x $1.00(\mathrm{v} / \mathrm{v}, \%) \mathrm{EMS} ; 4=\mathrm{T} 1 \times 1.25(\mathrm{v} / \mathrm{v}, \%) \mathrm{EMS} ; 5=\mathrm{T} 1$ $\mathrm{x} 1.25(\mathrm{v} / \mathrm{v}, \%)$ EMS.

\section{CONCLUSION AND FUTURE PROSPECTIVE}

In this study, we determined the biological effect of different EMS concentrations and conditions on first generation C. annuum var. B12 to assess their mutagenic sensitivity in first generation (M1) plants. Presoaking treatments significantly alters the effectiveness of EMS. A new presoaking treatment was used in this study (presoaked seeds in water for $6 \mathrm{~h}$ then incubate for $12 \mathrm{~h}$ at $28^{\circ} \mathrm{C}$ before treating with EMS). Five dwarf plants were observed from the T1 (dry seeds treated with EMS without presoaking). The $\mathrm{LD}_{50}$ was detected at about $1 \%$ EMS in $\mathrm{T} 1$ and $\mathrm{T} 3$, which is quite high, whereas the $\mathrm{LD}_{50}$ was relatively low for $\mathrm{T} 2$ and $\mathrm{T} 4(0.5 \%$ EMS). The germination percentage and survival percentage showed significant decreases with increasing EMS concentration under all tested presoaking treatments.

\section{ACKNOWLEDGMENTS}

Research supported by the National Natural Science Foundation of China (\#31272163) and the Shaanxi Provincial Science and Technology Coordinating Innovative Engineering Project (\#2012KTCL02-09). The authors wish to thank Dr. Lv Yuan-Hong, the director of vegetable center laboratory, for her valuable help. 


\section{REFERENCES}

Aslam U, Khan AAH, Cheema MNFI, and Malik W (2013). Kill curve analysis and response of ethyl methane sulfonate and $\gamma$-rays in diploid and tetraploid cotton. Int. J. Agric. Biol. 15: 11-18.

Association of Official Seed Analysis (1990). Rules for testing seeds. J. Seed Technol. 12: 1-112.

Bahar B and Akkaya MS (2009). Effects of EMS treatment on the seed germination in wheat. J. Appl. Biol. Sci. 3: 59-64.

Bashir S (2012). Studies on the Induction of Mutations in Fenugreek (Trigonella foenum-graecum L.). Master's thesis Univ. Kashmir, Hazratbal, Srinagar. India, 158.

Borovsky Y, Tadmor Y, Bar E, Meir A, et al. (2013). Induced mutation in $\beta$-carotene hydroxylase results in accumulation of $\beta$-carotene and conversion of red to orange color in pepper fruits. Theor Appl. Genet. 126: 557-565.

Bosland PW (1992). Chilies: A diverse crop. Hort. Technol. 2: 6-10.

Chopra VL (2005). Mutagenesis: investigating the process and processing the outcome for crop improvement. Curr. Sci. 89: 353-359.

Constantin MJ (1975). Mutations for Chlorophyll Deficiency in Barley. Comparative Effects of Physical and Chemical Mutagens. 96-112. In: Barley Genetics III. (H. Gaul, ed.) Proc. 3rd Int. Barley Genet. Symp. Garching, Germany, 7-12 July. Verlag Karl Thiemig, Munich.

Deepalakshmi AJ and Anandakumar CR (2004). Creation of genetic variability for different polygenic traits in black gram (Vigna mungo (L.) Hepper) through induced mutagenesis. Legume Res. 27: 188-192.

Devi SA and Mullainathan L (2011). Physical and chemical mutagenesis for improvement of chili (Capsicum annuum L.). World Appl. Sci. J. 15: 108-113.

Devi SA and Mullainathan L (2012). The use of ethyl methane sulfonate to study the flower development in Capsicum annuum L. mutants. Bot. Res. Int. 5: 04-09.

Devi SA and Selvakumar G (2013). Chemical mutagens induced alterations in chlorophyll mutants and flower development of chilli (Capsicum annuum L.). Int. J. Mod. Agric. 2: 39-42.

Dezfuli PM, Zadeh FS, and Janmohammadi M (2008). Influence of priming techniques on seed germination behavior of maize inbred lines (Zea mays L). J. Agric. Biol. Sci. 3: 22-25.

Dhamayanthi KPM and Reddy VRK (2000). Cytogenetic effects of gamma rays and ethyl methane sulphonate in chilli pepper (Capsicum annuum L.). Cytologia 65: 129-133.

Emrani N, Arzani A, and Saeidi G (2011). Seed viability, germination and seedling growth of canola (Brassica napus L.) as influenced by chemical mutagens. Afr. J. Biotechnol 10: 12602-12613.

Farooq M, Basra SM, Hafeezu AR, and Saleem BA (2008). Seed priming enhances the performance of late sown wheat (Triticum aestivum L.) by improving chilling tolerance. J. Agron. Crop. Sci. 194: 55-60.

Fowler DB and Stefansson BR (1972). Effects of the mutagenic agent ethyl methane sulfonate on the M generation of rape (Brassica napus). Can J. Plant Sci. 52: 53-62.

Gandhi ES, Devi AS, and Mullainathan L (2014). The effect of ethyl methane sulphonate and diethyl sulphate on chili (Capsicum annuum L.) in M1 generation. Int. Let. Nat. Sci. 5: 18-23.

GraphPad Prism Version 6.00 for Windows (2014). GraphPad Software, La Jolla California USA, Available at [www. graphpad.com].

Greene EA, Codomo CA, Taylor NE, Henikoff JG, et al. (2003). Spectrum of chemically induced mutations from a large scale reverse-genetic screen in Arabidopsis. Genetics 164:731-740.

Greer SP and Rinehart TA (2009). In vitro germination and dormancy responses of Hydrangea macrophylla and Hydrangea paniculata seeds to ethyl methane sulfonate and cold treatment. Hort Sci. 44:764-769.

Jabeen N and Mirza B (2002). Ethyl methane sulfonate enhances genetic variability in Capsicum annuum. Asian J. Plant Sci. 1: 425-428.

Jabeen N and Mirza B (2004). Ethyl methane sulfonate induces morphological mutations in Capsicum annuum. Int. J. Agric. Biol. 6: 340-345.

Khan S and Goyal S (2009). Improvement of mung bean varieties through induced mutations. Afr. J. Plant Sci. 3: 174-180.

Kumar APK, Boualem A, Bhattacharya A, Parikh S, et al. (2013). SMART - sunflower mutant population and reverse genetic tool for crop improvement. BMC Plant Biol. 13: 38.

Kumar G and Gupta P (2009). Induced karyo-morphological variations in three phenol-deviants of Capsicum annuum L. Turk J. Biol. 33: 123-128.

Ojiewo CO, Agong SG, Murakami K, Tanaka A, et al. (a) (2006). Chromosome duplication and ploidy level determination in African nightshade (Solanum nigrum L ssp. Villosum (L) Ehrh) J. Hortic. Sci. Biotechnol. 81: 559-564.

Patil AN, Meshram LD, and Nandanwar RS (1997). Induced quantitative variation in economic characters by chemical mutagens in chilli. J. Soils Crops 7: 15-8. 
Pavadai P and Dhanavel D (2004). Effect of EMS, DES and colchicine treatment in soybean. Crop Res. 28: 118-120.

Reddy VRK, Indra M, and Revathi R (1992). Meiotic abnormalities in Lentil (Lens cu/inaris Med/k) induced by gamma radiation, EMS and sodium azide. J. Cytol. Genet. 27: 1-10.

Saba N and Mirza B (2002). Ethyl methane sulfonate induced genetic variability in Lycopersicon esculentum. Int J. Agric. Biol 4: 89-92.

Sathawane KN (2012). Sodium Azide (sa) induced higher mutations frequency of yellow seed coat colour in Brassica juncea (L.) Coss. \& Czern. cv. Varuna. Bionano Frontier 5: 2 -11.

Serrat X, Esteban R, Guibourt N, Moysset L, et al. (2014). EMS mutagenesis in mature seed-derived rice calli as a new method for rapidly obtaining TILLING mutant populations. Plant Met. 10: 5 Doi: 10.1186/1746-4811-10-5.

Sharma V and Kumar G (2003). EMS induced viable macromutants in Cicer arietinum L. J. Cytol Genet. 4: 85-89.

Snedecor GW and Cochran GW (1980). Statistical methods. 7th edn. The Iowa State Univ. Press, Amer. Iowa, USA.

Statistix (2008) Statistix 9: Analytical Software. Available at [http//www.statistix.com]. Tallahasee, USA.

Talebi AB, Talebi AB, and Shahrokhifar B (2012). Ethyl methane sulphonate (EMS) induced mutagenesis in Malaysian rice (cv. MR219) for lethal dose determination. Am J. Plant Sci. 3: 1661-1665.

Velu SL, Mullainathan D, Arulbalachandran D, Dhanavel R, et al. (2007). Effectiveness and efficiency of gamma rays and EMS on cluster bean [Cyamopsis tetragonoloba (L.) Taub.] Crop Res. 34: 49-251. 